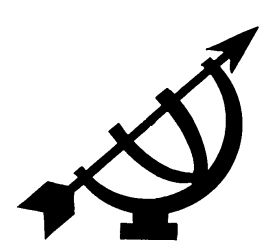

\title{
The dilemma of ethical political communication in South African elections
}

\author{
Lynnette M. Fourie \& Johannes D. Froneman \\ School of Communication Studies \\ Potchefstroom Campus \\ North-West University \\ POTCHEFSTROOM \\ E-mail: Lynnette.Fourie@nwu.ac.za \\ JD.Froneman@nwu.ac.za
}

\section{Abstract \\ The dilemma of ethical political communication in South African elections}

In view of South Africa's diversity, its unresolved issues of race and complex social legacy, election campaigns are highly sensitive. From a Reformed Christian perspective, a critical question is: To what extent is the political culture infused by the Biblical imperatives of brotherly love, respect and compassion? Given the growing use of adversarial political advertising the following two questions arise and are specifically addressed:

- Could it realistically be expected of Christian political communicators in a secular country such as South Africa to communicate with full respect to people at all times, or should they be excused if they try to win at all costs? and

- How do political theorists view the issue?

In answering these questions, social responsibility and the need for social harmony as precondition for free and fair political activities, as well as a Biblical perspective on communication are addressed. In view of these theoretical points of departure the role of emotional messages is discussed and evaluated.

It is argued that all advertising, but specifically political advertising in an emotionally charged atmosphere such as an election campaign, could have a direct negative impact on social harmony and is therefore Biblically unacceptable. Examples 
from previous South African general elections are discussed and evaluated from a Biblical viewpoint. It is argued that parties should not merely campaign with the aim of winning an election, but rather with the intention of respecting voters while campaigning. Simultaneously they could promote democracy within a fragile social context. Any victory outside of these parameters will not stand the test of a Biblical critique.

However, it would seem extremely difficult, if not impossible, to prescribe in any detail which types of negative advertisements are acceptable and which are not.

\section{Opsomming}

\section{Die dilemma van etiese politieke kommunikasie in Suid- Afrikaanse verkiesings}

In die lig van Suid-Afrika se diverse samelewing, onopgeloste rassekwessies en 'n komplekse sosiale nalatenskap, is verkiesingsveldtogte hoogs sensitiewe aangeleenthede. Vanuit 'n reformatories-Christelike perspektief is 'n kritieke vraag die volgende: Tot watter mate is ons politieke kultuur deurdrenk met die Bybelse eise van naasteliefde, respek en medelye? Met die groeiende gebruik van politieke aanvalsadvertensies in gedagte, duik die volgende twee vrae op wat spesifiek aan die orde gestel word:

- Is dit realisties om van Christen-politieke kommunikeerders in 'n sekulêre samelewing soos Suid-Afrika te verwag om in alle gevalle respekvol met kiesers te kommunikeer, of kan hulle verskoon word as hulle probeer om 'n verkiesing ten alle koste te wen? en

- Hoe oordeel politieke kommunikasie-teoretici oor die saak?

Om hierdie vrae te help beantwoord, word 'n Bybelse perspektief op kommunikasie kortliks voorgehou. Verder word sosiale verantwoordelikheid en die noodsaaklikheid van sosiale harmonie as voorvereistes vir vrye en regverdige verkiesings bespreek. Laastens word die rol van emosioneelbelaaide boodskappe in 'n verkiesing bespreek en beoordeel.

Daar word geargumenteer dat reklame, veral politieke reklame, in 'n emosiebelaaide atmosfeer (soos 'n verkiesingsveldtog) ' $n$ negatiewe uitwerking op sosiale harmonie kan hê. Toepaslike voorbeelde uit vorige Suid-Afrikaanse algemene verkiesings word bespreek en geëvalueer.

Die gevolgtrekking word gemaak dat politieke partye, vanuit 'n Bybelse perspektief, nie net stemme moet werf met die oog daarop om 'n verkiesing te wen nie, maar hulle moet met respek teenoor alle kiesers optree. Terselfdertyd kan stabiliteit en 
harmonie in die jong demokrasie bevorder word. Enige oorwinning buite hierdie parameters sal nie die toets van Bybelse kritiek kan deurstaan nie.

Dit is egter baie moeilik, indien nie onmoontlik nie, om gedetailleerde riglyne neer te lê oor watter tipe negatiewe boodskappe aanvaarbaar is en watter nie.

\section{Introduction}

Free and fair elections are necessary for any democracy, but it does not guarantee democracy (cf. Bratton \& Chang, 2006) - certainly not a democracy in which Christians committed to proclaiming the Lordship of Christ would be comfortable in. The manner in which elections are conducted, is a better indicator of political culture. From a Reformed Christian perspective, the critical question ought to be: To what extent is political culture infused by the Biblical imperatives of brotherly love, respect and compassion? This question, we believe, is not out of place in a nominally secular country such as South Africa, as the majority of the country profess some allegiance to the Christian faith and many prominent political leaders and candidates are committed Christians.

Elections are not only indicators of democracy, but also an important part of the democratic process itself. Elections are also opportunities for political parties to engage, inter alia through advertising, with the electorate on policy issues and to encourage voters to participate in the democratic process. The manner in which they communicate is thus of the utmost importance. Is adversarial political advertising, for instance, prudent in a potentially fragile political environment?

In the past elections no statutory or self-regulatory body has accepted full responsibility for ensuring that political communication, in particular advertising, adhered to certain standards. The responsibility has floundered between a number of bodies governed by different acts (cf. Icasa, 2004; ASA, 2007). The importance of sustaining democracy was, however, recognised by South African political parties in signing a code of conduct on 1 March 2004.

Notwithstanding this and other pledges, there are enough examples to indicate that the adversarial approach is practiced in election campaigns, possibly to the detriment of general social harmony. We would argue that if political culture is not developed correctly, a growing adversarial approach could well become a real problem and progressively alienate our society from what is Biblically acceptable 
and politically sensible. The primary questions thus addressed in this article are:

- Should it be expected of political parties in a secular country such as South Africa to communicate with "full respect" for people at all times, or could they be excused if they try to win at all cost, even if it could have a harmful impact on the general social harmony of a diverse society? and

- How do political theorists view the issue of negative political advertising and social harmony?

We therefore investigate whether South African political parties have shown social responsibility and general respect for people through their political communication during the past elections. More specifically, we posit an ethical perspective, based on Biblical principles, which suggests that winning at all costs is not morally acceptable in our (or any other) context. We believe that sustaining and growing the democracy in order to support a human rights culture and Biblical respect for God's children are worthwhile objectives for all Christians involved in politics.

We will attempt to answer the stated questions by addressing the issues from a Reformed Christian perspective and by exploring the ongoing debate in literature regarding the use of negative messages in election campaigns.

Furthermore, South African political parties will be evaluated by focusing on examples from the 1999 and 2004 general elections. The article thus poses certain fundamental questions, provide examples of questionable political advertising and conclude with some remarks about the dilemma of Christian political communicators in a secular environment.

\section{Theoretical points of departure}

\subsection{Christian perspectives on political communic ation}

Advertising continually elicits wide reaction and more often condemnation. Given the ubiquitous character of advertising in consumer-oriented societies, this is not surprising. In a country still dealing with unresolved issues of race and culture and a complex socio-political legacy, one could argue that all advertising needs to tread warily, without, of course, denying the clear rights enshrined in the Bill of Rights. 
Actively promoting social harmony may not be a constitutional imperative, but all communication practitioners (including those advising political parties, campaign managers and those who approve political advertisements in all its forms) clearly have a social responsibility or duty in this regard - a social contract to fulfil and moral choices to make (cf. Hiebert et al., 1991:205, 206).

If there is a need to take the general obligations in young and brittle democracies seriously, the challenge to respect Biblical imperatives is even more urgent. As Day (2006:30) remarks in general about moral duties:

Society imposes certain responsibilities on its constituents as a condition of membership ... The idea of duty to others is important to moral reasoning because it is a way of paying homage to the triumph of virtue over self-interest.

But clear general moral imperatives can easily get lost in the heat of election campaigns and the fog of intricate arguments regarding negative advertising. Christians could get some clarity by revisiting some fundamental Biblical points of departure regarding communication as such.

Our point of departure is that our whole life ought to be religion, service to God (cf. Botha, 1993:107-108; Spykman, 1985:35). As our primary citizenship is not in South Africa, but in heaven (Phil. $3: 20$; 1 Pet. 3:11), we are called not to conform to the pattern of this world, but to be transformed by the renewing of our mind (Rom.12:2; Eph. 4:23, 24). The Word of God urges us to live carefully (Eph. $5: 15$ ), to be holy (1 Pet.1:16), certainly also in our political activities. Therefore, as Van der Walt (1991:43) states in discussing a Reformed worldview, we believe:

... that man's religious relation to God is total: it yeasts through everything one does; it is radical; from out of a heart commitment it offers security to one's entire existence; it is central: it offers direction and purposefulness to one's whole life; it is integral: it binds together everything that one does to a meaningful whole.

While sin has had a radically corrosive effect on our ability to know, to act and to communicate effectively, we ought to strive to communicate differently from the world - even when we are busy with such a very worldly activity as electioneering. 
With reference to Christian scholars such as Veenstra (1994:71-85), Snyman (1994:43-70; 1985:9-23), Velema (1991:109-125), Van Delden (1990:251-218), Van Velzen (1990:199-203), Stoker (1967: 5456), De Vries (1979), Christians, Ferré and Fackler (1993) and Kennedy (1972), one could identify a few Biblical principles applicable to communication. They include the following (cf. Froneman, 1997:5$6)$ :

- Communication (including political communication) is a god-given gift which has to be used with love and responsibility, which implies, inter alia, that political communicators should try to win voters' support in such a way that full respect and compassion be afforded to all people concerned.

- Voters deserve full respect as reflections of God's image (cf. Johannesen, 1990:89; Veenstra, 1994). We should thus communicate with them in a respectful spirit.

- Political communication should ideally help people to realise their potential and fulfil their individual callings by proclaiming the Lordship of Jesus over every sphere and structure of human activity (cf. Atwood, 1998). This clearly includes political communication during elections.

In view of these principles, one can state that political communicators ought to provide comprehensive information on all relevant political issues as this helps to orientate voters and empower them to fulfil their calling (cf. Snyman, 1994:66; Van Vlastuin, 1998:2344). This political information needs to be timely, i.e. fresh enough to be of use. It also has to be reliable, undistorted and accurate. Furthermore, it has to be understandable, a point of particular importance in a country with low literacy (cf. Froneman, 1997:6-8). As such, political advertising should strive to serve the public debate, not pervert it with obfuscation and lies.

Christian political communicators ought to serve voters by caring for them in a loving way (liefdevolle persoonsbehartiging) as Snyman (1994) suggests in another context. This caring political communication should serve voters by orientating them (cf. Van Vlastuin's [1998:28] notion of oriënterende persoonsbehartiging). This implies that all communication, including political communication in the form of advertising, not only has structure, but direction (cf. Van Vlastuin, 1998:29-31). Is it asking too much to suggest that political parties, at least the Christians active in the field, "must also consider whether 
the particular communication helps people on their journey towards the face of God" (Veenstra, 1994:81)?

Adversarial political advertisements tend to concentrate on making a negative point, thereby neglecting the serious information needs of voters (cf. Elliot, 1995:260-262). This cannot be condoned as it erodes the public sphere as an intellectual meeting place.

On the other hand, the point of political debate and communication, is to convince voters that you are the better choice. The crux probably lies in the question if it is necessary, recommendable or even ethical to demonise the opposition. While one could, from a Biblical point of view, easily answer in the negative, the following version of the same dilemma is more difficult to answer: Is it incumbent on a Christian politician to "defend and promote, as much as I am able, the honour and good character of my neighbour", as required by the Heidelberg Catechism? If my "neighbour" refers to all people, it surely also includes my political opponents, i.e. my political "enemies".

These questions clearly places the whole issue within the realm of political philosophy. In order to provide answers to the abovementioned questions, the discourse should ideally also be addressed at a meta-ethical level, which unfortunately falls outside the realm of this article. For this reason this article is but a partial attempt at addressing a very broad issue.

\subsection{Theoretical perspective on the use of negative political messages}

Coinciding with the increasing application of an asymmetric marketing model to political communication, the use of negative messages are increasing world-wide (Kaid \& Johnston, 1991; Hodess et al., 2000; Robideaux, 2004; Young, 2003). Desposato (2007) confirms that negative campaigning is also increasing in developing democracies, for example in Mexico, India and Brazil. The competitive nature of an asymmetric marketing model implies that it is not enough to promote the own party, the opposition has to be denigrated. This could well be in conflict with Christian norms.

Broadly speaking there could be distinguished between truly comparative and negative advertisements. Comparative advertisements aim to highlight the weaknesses of the opposition by comparing it with the parties' own strong points (cf. Johnson-Cartee \& Copeland, 1991:43; Kolodny et al., 2000). Negative messages only refer to the 
opposition party (cf. Kern, 1989:102-104; Johnson-Cartee \& Copeland, 1997:16; Hughes, 2003; Kahn \& Kenney, 1999). This message could refer to policy issues, unfulfilled promises, personal characteristics of leaders and past mistakes (see Johnson-Cartee \& Copeland (1991) for an overview of different tactics used in negative advertisements).

Social harmony could thus easily be harmed. In short, this is a potentially devastating issue with strong ethical implications.

There is a magnitude of literature regarding the effectiveness and "appropriateness" of negative advertising. Conventional wisdom, especially among practitioners, holds that negative campaigning is very successful although disliked by the electorate (cf. Lariscy \& Tinkham, 1999; King \& McConnel, 2003:843-844; Robideaux, 2004: 222). However, there is also evidence (although results have not been consistent) that negative campaigning could have a boomerang effect and therefore discredit the sponsoring party (see Garramone \& Smith, 1984; Sonner, 1998; Abbe \& Hernson, 2000; Merritt, 1984).

All these arguments are clearly pragmatic and neglect to address the issue from a moral viewpoint grounded in a particular worldview. From a specifically Christian point of view, a deontological ethical approach is suggested which requires political communicators to accept that they have a duty towards God and their neighbour (the voters) to communicate ethically (cf. Froneman \& De Beer, 1998: $293,294)$. A teleological approach which only cares about outcomes may be attractive to those trying to win an election, but cannot stand the test of the Biblical duty.

However, we do not suggest a simplistic deontological approach. The consequences of our actions are indeed relevant and need to be considered when communicating. But to abdicate one's responsibility due to political expediency, is Biblically unacceptable.

A second issue suggested by researchers is that negative messages demobilise the electorate (Ansolabehere et al., 1994; Ansolabehere \& lyengar, 1995). Their findings have been confirmed by various other studies (cf. Abbe \& Hernson, 2000; Turner, 2001; Rahn \& Hirshorn, 1999). This is especially relevant for South Africa where voter turn-out has declined from $89,3 \%$ of registered voters in 1999 to $76,7 \%$ in 2004 (Schulz-Herzenberg, 2007:117). If indeed negative political advertisements demobilise voters, this would imply 
that these advertisements do not comply to the ethical norm of caring for the voters.

On the other hand the demobilising effect of negative messages has been questioned in more recent studies (cf. Kahn \& Kenny, 1999; Wattenberg \& Brains, 1999; Finkel \& Geer, 1998; Just \& Crigler, 1999; Brooks, 2006). These arguments centre around the notion that negative messages are more informational (see Gillespie, 2006; Johnson-Cartee \& Copeland, 1991:278; Kaid, 1999:427; Stevens, 2005) and better remembered (Lariscy \& Tinkham, 2004; Shapiro \& Rieger, 1992:144).

The worth of negative advertising could be explained by the possibility that negative messages are more likely to contain "hard evidence" regarding a point of view (Geer, 2006). Negative advertisements often provide information on candidates' (and parties') deficiencies, thus balance positive, but information-free messages (Kahn \& Kenney, 1999:878; Kolodny et al., 2000; Geer, 2006; Desposato, 2007).

If this were the case, then political advertising would actually adhere to the norm of caring political communication in that they were informing and orientating the voter. This also underlines the argument made above that the ethics of political communication cannot be too precious: what seems "unacceptable" may gain in worth if the positive consequences are factored in.

Recent studies have indicated that negative messages could actually motivate the electorate to vote. Their emotional appeals encourages participation by the electorate (Garromone et al., 1990: 302; Martin, 2004), and negative campaigns stimulate problem awareness, which leads to anxiety about candidates or parties. Voters therefore percieves the election and election outcome as something more personal (Martin, 2004). This finding is likewise important in a country such as South Africa where there is, at least at the moment, a dominant party who was not in danger of losing the last elections.

From the above it is clear that negative messages, especially advertisements, form an important part of electioneering and also the focus of academic research and debate. However, there is very little consensus among researchers regarding the effect and effectiveness of negative campaign messages. Different explanations have been offered for these contradicting results and conclusions, including different cultural circumstances (cf. Finkel \& Geer, 1998); 
different perceptions of negative messages (Sigelman \& Kugler, 2003; Kahn \& Kenney, 1999); differences in the application of research methodology (Brooks, 2006; Kahn \& Kenney, 1999); voter loyalties and source credibility (Yoon et al., 2005); and different levels of political knowledge and sophistication (Kahn \& Kenney, 1999; Yoon et al., 2005; Desposato, 2007).

From research within the field of political communication, it is thus clear that negative messages should be used with caution in a young democracy. If the Biblical imperative to communicate with care is added, it is clear that negative electioneering need to be treated discriminately. To take the argument further, we have to distinguish between different kinds of negative messages. Particularly in a young, diverse democracy negative messages aimed at discrediting leaders (without sound reasons) or insulting other racial groups are regarded as detrimental to democracy and therefore not supportive of social harmony. On the other hand, messages stimulating debate, within the boundaries of social harmony, could contribute to the fostering of a robust democratic political culture. Negative political communication can thus not be regarded as unethical per se.

In view of the above theoretical arguments the use of negative advertising in the two most recent national elections in South Africa will now be discussed and evaluated.

\section{Negative messages in South Afric an elections}

Some examples of negative messages, drawn from a comprehensive qualitative analysis of election campaigns (Fourie, 2003), will illustrate the different types of negative messages used in 1999 and 2004 national election campaigns. It should provide sufficient empirical evidence to illustrate the dilemma of winning elections while communicating ethically, particularly from a Biblical perspective, on (political) communication.

The first cluster of negative messages identified typical problems in South African society. As could be expected these messages were mainly utilised by opposition parties and especially the Democratic Party (DP) in 1999 and the Democratic Alliance (DA) in 2004. The advertisements (both print and radio) of the DP focused on crime (especially rape and murder), corruption and unemployment and the government's inability to address these issues. A 1999 radio advertisement stated for example: 
The news from South Africa: Since the ANC took power an average of 132 women raped every day. An average of 71 South Africans, whites, blacks, coloureds and Indians murdered every day, 500000 jobs lost, at least 20000 million rand stolen by corrupt government officials ...

This theme was continued by the DA in 2004 in their radio advertisements, for example:

... Murder, rape, child abuse and the criminals get away with it, South Africa deserves better, the DA will put 150000 police on our street, train them, equip them and stop the criminals, no more pardons, no more excuses. Tougher sentences, that is the DA plan. Vote DA for real change, because South Africa deserves better.

The New National Party's (NNP) advertisements in 1999 had basically the same message, for example:

Crime is threatening the very fabric of society. No one is safe any more. Is there a solution?

Although the same issues were still highlighted by the NNP in 2004, a different solution was presented. The African National Congress (ANC) was no longer depicted as the problem; the working agreement between the NNP and the ANC was now the solution:

I never saw them coming, I felt the gun against my head, they demanded my car. I felt like a victim. I want to use my vote to help fight crime. You have the choice to make your voice heard. If you believe in safety and protection, then make your voice heard. I am Marthinus van Schalkwyk, leader of the NNP. A vote for the NNP is your key to government. The NNP. Let us by your voice.

In the above-mentioned negative messages the techniques of referring to the hard reality, broken promises and the record of the ruling party were used to portray the ANC in a bad light. These messages could be seen as highlighting problems in society and also stimulating debate. Furthermore the constant reference of the DP to the power of the voter also implied that if voters wanted to achieve something, they had to vote. Such voters were empowered and inspired to fulfil their obligations or Christian calling. The above-mentioned message was directed at countering the feeling under voters from minority groups that it was futile to vote. However, these messages could also have affected the democracy negatively in that it portrayed South Africa in a bad light. This could have implied that 
the democracy was not functioning as it should and could have left the electorate feeling despondent. But one could argue that human life and liberty were appropriately highlighted and that voters were orientated with regard to the issues that demanded a responsible decision of them.

The second group of messages compared policies from different parties with each other. These negative comparative messages were especially used during the 1999 election campaigns. The NNP had print advertisements referring to the death penalty, policing and abortion, suggesting that the DP was, in terms of these policy issues, closer to the ANC than to the NNP. Along the same line of thought, the Freedom Front Plus (FF+) had a series of print advertisements referring to the Truth and Reconciliation Commission, land claims, illegal removals, abortion, lottery and gambling regulation, and pensions, suggesting that the ANC, NNP and DP all supported the proposed legislation, while the FF+ opposed it. Although these messages addressed emotional issues, they were generally not presented overly emotional and could well have stimulated debate and thus enhanced the democracy. As such one could argue that they served the voter, particularly the Christian voter who were opposed to the legislation of gambling and abortion. The implication that the DP supported a libertarian approach to abortion was not true. The party allowed its members a free vote on this issue.

There were, however, also negative messages in the election campaigns that were potentially harmful for a young democracy. In 1999 there were several examples of personal attacks on leaders. The DA, for example, depicted Winnie Madikezela-Mandela in military uniform in a print advertisement with quotes from the Truth and Reconciliation Commission's report finding her guilty of the violation of gross human rights with the caption Jy kan hierdie vrou stop. An ethical question one could ask about this attack, is: Was the military image portrayed of her true? If so, was it not the duty of the DA to convey this to voters? In the same mode Nkozana Zuma's picture appeared in an advertisement with the caption Vertrou jy hierdie vrou met 'n tweederde-meerderheid? Ons ook nie. Was it unethical to suggest that Zuma was not to be trusted? Could this be regarded as a form of slander? And how does this measure up to the injunction that we are required, as Christians, to defend your neighbour's good name?

It could probably be argued that the DP was referring to the leaders' track records and merely indicating that the leaders were not appropriate for a democracy. However, these advertisements made 
very personal attacks and did not refer to any policy issues. On the other hand, voters probably knew the background to the short-hand advertisements.

More personal was the advertisements of the NNP questioning Tony Leon's religious background, quoting: ... my lewe word nie gerig deur godsdienstige wette en rituele nie. This raises the issue of functioning as Christians within a multi-religious, even secular, environment. Is your non-Christian opponents not worthy of respect? Should they be denigrated for not sharing your faith? And does the fact that they are not Christians rule out the possibility that they may be right? How would Christian politicians react if they were dismissed for being believers? The Biblical injunction of doing unto others as one would do unto oneself seems appropriate.

The NNP continued its attack on Tony Leon in 2004, although there was a stronger emphasis on policy. They accused the DA of false promises indicating that Tony Leon did not have the power to build one house or put one policeman on the street. While all politicians made promises to some extent, it is incumbent on them to be realistic and therefore truthful. If a politician breaches that rule, one is clearly entitled to point it out.

For the most part the ANC as governing party's election campaign reflected positive messages. However, in the 1999 campaign they used the "Fight Back" slogan of the DA against them in the Western Cape. The ANC displayed posters in the colours of the DA with the slogan Don't Fight Blacks. This implied that the DA encouraged (white) voters to fight black people, which was not the case. It was an example of irresponsible, unethical opportunism. But in the context of the election, one could, in retrospect, also question the belligerent slogan of the DA.

In 2004 the DA started to target other opposition parties besides the ANC. A part of the campaign message of the DA was to unite the opposition and this was especially deployed in its radio advertisement campaign. It had a series of advertisements with the basic position that the DA and its partners could win $30 \%$ of the vote. All these advertisements ended with the slogan: Unite behind the DA and help build a new majority in South Africa. The unite-theopposition-theme was also echoed in its poster and pamphlet campaigns. Underlying this was the notion that a vote for a smaller party would be a "wasted" vote. In two of these advertisements the DA named the FF+ and Independent Democrats (ID) and implied that a vote for them will be a wasted vote, for example: 
I was thinking of voting for Patricia de Lille's Independent Democrats, but I am not going to. I am voting DA instead, because I don't want to split the opposition and South Africa needs a strong alternative to the ANC. I like De Lille, but she is really just a one-woman show ...

The DA, also questioned the volkstaat policy of the FF+ in the radio advertisements as well as pamphlets featuring a photo of a "desert" in the Northern Karoo, asking the question whether the voter would like to live there.

Although it was not explicitly stated that a vote for the NNP would be wasted, the DA inferred that a vote for the NNP would be a vote for the ANC and therefore a vote against the opposition:

Marthinus van Schalkwyk has betrayed NNP supporters in exchange for a job. He gave the ANC power. If you vote NNP you will give the ANC power in the Western Cape again. Keep the ANC out.

The FF+ reacted by means of a radio advertisement:

Die DA praat van gemorsde stemme maar almal weet jy kan nie jou stem in ons stelsel mors nie. Dit was die DA wat voorgestel het dat politici met my stem kan oorloop na 'n ander party. Dit is nou gemorsde stemme. Voor my DA-stem dalk oorloop na die ANC, maak ek eerder doodseker en stem Vryheidsfront Plus.

The DA, NNP and FF+ were thus now communicating with each other through their adversarial advertisements. Although this could be seen as stimulating debate, it could very easily result in mudslinging distracting the voter from real election issues and also disrupt social harmony. Whether these advertisements were in conflict with the Biblical principles stated earlier, is not so clear. Political parties differ on tactics and severely criticise each other in this regard. If no male fide is implied, should one not accept it as part of political discourse.

Negative messages were thus part and parcel of the 1999 and 2004 election campaigns. In view of the research findings and our brief comments, it could be concluded that these messages may well have strengthened the democracy, but could have threatened social harmony in South Africa, especially when highlighting issues of race. In some instances one could seriously question the ethical validity of the political communication. 


\section{Conclusions}

Given the peaceful circumstances in which the last two general elections took place in South Africa, it could be argued that the use of negative and comparative messages did not have any noticeable harmful effect, although some of the messages led to racial tension. It could thus be concluded that the democracy should be allowed to mature without unnecessary intervention, as freedom of speech is the primary concern.

Although it seems as if no harm has yet been done, there are compelling arguments which suggest that negative electioneering may well have a detrimental long-term effect on democracy. We therefore argue that parties should not merely campaign with the aim to win an election, but rather with the intension to campaign with full respect for voters. Simultaneously they could promote democracy and the fragile social context in which it functions. Any victory outside of these parameters will not stand the test of a Biblical critique.

Christian political communicators in particular, need to take cognisance not only of clear Biblical principles of love, respect and compassion when engaging the populace in political discourse, but also of political theory regarding negative political advertising.

The example set by Christians who proclaim the Lordship of Christ in all circumstances could contribute significantly to a more mature, caring political culture. We believe that they ought to refuse to surrender their Christian principles in order to win elections at all costs. However, it would seem extremely difficult, if not impossible, to prescribe in any detail which types of negative or adversarial advertisements are acceptable and which are not.

\section{List of references}

ABBE, O.G. \& HERNSON, P.S. 2000. Going negative does not always mean getting ahead in elections. Campaigns and elections, 21(1):77-79.

ADVERTISING STANDARDS AUTHORITY. 2007. http://www.asasa.org.za/ Date of access: 18 Aug. 2007.

ANSOLABEHERE, S. \& IYENGAR, S. 1995. Going negative: how political advertisements shrink and polarize the electorate. New York: MacMillan.

ANSOLABEHERE, S., IYENGAR, S., SIMON, A. \& VALENTINO, N. 1994. Does attack advertising demobilize the electorate? American political science review, 88(4):829-838.

ASA

see ADVERTISING STANDARDS AUTHORITY

ATWOOD, R. 1998. Constructing a Christian model of journalism and the public sphere. Potchefstroom: PU for CHE. (Unpublished class notes.) 
BOTHA, M.E. 1993. Metateoretiese perspektiewe op die sosiale wetenskappe. Potchefstroom: $\mathrm{PU}$ vir $\mathrm{CHO}$.

BRATTON, M. \& CHANG, E.C.C. 2006. State building and democratization in Sub-Saharan Africa: forwards, backwards or together. Comparative political studies, 39(9):1059-1083.

BROOKS, D.J. 2006. The resilient voter: moving toward closure in the debate over negative campaigning and turnout. The journal of politics, 68(3):684696.

CHRISTIANS, C.G., FERRE, J.P. \& FACKLER, P.M. 1993. Good news: social ethics and the press. New York: Oxford University Press.

DAY, L.A. 2006. Ethics in media communication. London: Wadsworth.

DE VRIES, J.P. s.a. Normen voor journalistiek. Paper presented at the Evangelische Hogeschool Amersfoort, The Netherlands. Amersfoort: Evangelische Hogeschool.

DESPOSATO, S. 2007. The impact of campaign messages in new democracies: results from an experiment in Brazil. http://scholar.google. com/scholar?q=\%22the+impact+of+campaign+messages+in+new+demo cracies\%22+\&hl=en\&lr=\&btnG=Search Date of access: 25 Aug. 2007.

ELLIOT, P. 1995. Intellectuals, the "information society" and the disappearance of the public sphere. (In Boyd-Barrett, O. \& Newsbold, C., eds. Approaches to media: a reader. London: Arnold. p. 260-262.)

FINKEL, S.W. \& GEER, J.G. 1998. A spot check: casting doubt on the demobilizing effects of attack advertising. American journal of political science, 42(2):573-595.

FOURIE, L.M. 2003. Partybeheerde kommunikasie in die Noordwesprovinsie tydens die Suid-Afrikaanse algemene verkiesing van 1999. Potchefstroom: Noordwes-Universiteit. (Ongepubliseerde proefskrif.)

FRONEMAN, J.D. 1997. Towards a Christian model for journalism. Koers, 62(1):1-18.

FRONEMAN, J.D. \& DE BEER, A.S. 1998. Media ethics: thorny questions with diverse answers. (In De Beer, A.S., ed. Mass media: towards the millennium. Pretoria: Van Schaik. p. 249-268.)

GARRAMONE, G.M., ATKIN, C.K., PINKLETON, B.E. \& COLE, R.T. 1990. Effects of negative political advertising on the political process. Journal of broadcasting and electronic media, 34(3):299-31.

GARRAMONE, G.M. \& SMITH, S.J. 1984. Reactions to political advertising: clarifying sponsor effects. Journalism quarterly, 61(4):771-775.

GEER, J.G. 2006. Nasty, brutish and short: every one hates political attack ads - but they're informative and crucial to our democracy. Los Angeles Times: 23 Apr. http://webserve.govst.edu/pa/Political/Complaints/attack. htm Date of access: 25 Aug. 2007.

GILLESPIE, N. 2006. The positives of negative campaigning. Reason, 28(6):2.

HIEBERT, R.E., UNGURAIT, D.F. \& BOHN, T.W. 1991. Mass media VI: an introduction to modern communication. New York: Longman.

HODESS, R., TEDESCO, J.C. \& KAID, L.L. 2000. British party election broadcasts. Harvard international journal of press/politics, 5(4):56-57.

HUGHES, A. 2003. Defining negative political advertising: definition, features and tactics. Paper presented at the ANZAC Conference, 1-3 December, Adelaide, Australia. http://smib.vuw.ac.nz:8081/WWW/ANZMAC2003/ authors.php Date of access: 25 Aug. 2007. 
ICASA

\section{see INDEPENDENT BROADCASTING ASSOCIATION OF SOUTH} AFRICA

INDEPENDENT BROADCASTING ASSOCIATION OF SOUTH AFRICA. 2004. http//www.icasa.org.za Date of access: 7 Jul. 2004.

JOHANNESEN, R.L. 1990. Ethics in human communication. Prospect Hights: Waveland.

JOHNSON-CARTEE, K.S. \& COPELAND, G.A. 1991. Negative political advertising coming of age. New Jersey: Erlbaum.

JOHNSON-CARTEE, K.S. \& COPELAND, G.A. 1997. Manipulation of the American voter: political campaign commercial. Westport: Praeger.

JUST, M. \& CRIGLER, A. 1999. Voice, substance and cynicism in presidential campaign media. Political communication, 16(1):25-45.

KAHN, K.F. \& KENNEY, P.J. 1999. Do negative campaigns mobilize or suppress turnout? Clarifying the relationship between negativity and participation. American political science review, 93(4):877-889.

KAID, L.L. 1999. Political advertising. (In Newman, I., ed. Handbook of political marketing. Thousand Oaks: Sage. p. 423-438.)

KAID, L.L. \& JOHNSTON, A. 1991. Negative versus positive television advertising in the US presidential campaigns 1960-1988. Journal of communication, 41(4):53-65.

KENNEDY, J. 1972. The reformation of journalism. Toronto: Wedge.

KERN, M. 1989. 30 Second politics: political advertisements in the eighties. New York: Praeger.

KING, J.D. \& McCONNEL, B. 2003. The effect of negative campaign advertising on vote choice: the mediating influence of gender. Social science quarterly, 84(4):843-857.

KOLODNY, R., THURBER, J.A. \& DULIO, D.A. 2000. Producing negative ads: consultants review. Campaigns and elections, 21(7):56-57.

LARISCY, R.A.W. \& TINKHAM, S.F. 1999. The sleeper effect and negative political advertising. Journal of advertising, 28(4):13-30.

LARISCY, R.A.W. \& TINKHAM, S.F. 2004. Accentuating the negative. US today magazine: 18-19, May.

MARTIN, P.S. 2004. Inside the black box of negative campaign effects: three reasons why negative campaign mobilize. Political psychology, 25(4):545562.

MERRIT, S. 1984. Negative political advertising: some empirical findings. Journal of advertising, 13(3):27-38.

RAHN, W. \& HIRSHORN, R.M. 1999. Political advertising and public mood a study of children's political orientations. Political communication, 16(4): 387-407.

ROBIDEAUX, D.R. 2004. A longitudinal examination of negative political advertising and advertisement attitudes: a North American example. Journal of marketing communications, 10:213-224.

SCHULZ-HERZENBERG, C. 2007. A silent revolution: South African voters, 1994-2006. (In Buhlungu, S.D., ed. State of the Nation: South Africa 2007. Cape Town: HSRC. p. 114-143.)

SHAPIRO, M.A. \& RIEGER, R.H. 1992. Comparing positive and negative political advertising on radio. Journalism quarterly, 69(1):135-145. 
SIGELMAN, L. \& KUGLER, M. 2003. Why is research of negative campaigning so inconclusive? Understanding citizens' perceptions of negativity. The journal of politics, 65(1):142-160.

SNYMAN, P.G. 1994. A Christian perspective on the ethics of journalism. Ecquid novi, 15(1):43-70.

SONNER, B.S. 1998. The effectiveness of negative political advertising: a case study. Journal of advertising research, 38(6):37-42.

SPYKMAN, G.J. 1985. Spectacles: Biblical perspectives on Christian scholarship. Potchefstroom: PU for CHE.

STEVENS, D. 2005. Separate and unequal effects: information, political sophistication and negative advertising in American elections. Political research quarterly, 58(3):413-425.

STOKER, H.G. 1967. Oorsprong en rigting. Bd. 2. Kaapstad: Tafelberg.

TURNER, J. 2001. The negative campaign: New Labour, Ken Livingstone and the London mayoral selection process. Media culture and society, 23(2):257-265.

VAN DELDEN, J.A. 1990. De macht van de media. Bybel en wetenschap, 15(136):215-218.

VAN DER WALT, B.J. 1991. Anatomy of reformation. Potchefstroom: IRS.

VAN VELZEN, N.C. 1990. Nieuwsgaring en -selectie: een kwestie en principe. Bybel en wetenschap, 15(136):199-203.

VAN VLASTUIN, E. 1998. Die joernalistieke oriëntasiefunksie van Beeld, Rapport en Die Kerkbode ten opsigte van homoseksualiteit, aborsie en dobbelary. Potchefstroom: PU vir CHO. (Ongepubliseerde M.A.-verhandeling.)

VEENSTRA, C. 1994. A Christian view on ethics and communication. Ecquid novi, 15(1):71-85.

VELEMA, W.H. 1991. Krant en ethiek. (In Van der Ros, B., red. Het Christelijke dagblad in de sameleving. Leiden: Groen. p. 109-125.)

WATTENBERG, M.P. \& BRAINS, C.L. 1999. Negative campaign advertising: demobilizer or mobilizer? American political science review, 93(4):891899.

YOON, K., PINKLETON, B.E. \& KO, W. 2005. Effects of negative political advertising on voting intention: an exploration of the roles of involvement and source credibility in the development of voter cynicism. Journal of marketing communications, 11(2):95-115.

YOUNG, S. 2003. Scare campaigns: negative political advertising in Australia. Paper presented to the Australasian Political Studies Association Conference, University of Tasmania, Hobart, 29 September-1 October 2003.

\section{Key concepts:}

Christian worldview and political communication negative electioneering

political communication ethics

South African elections

\section{Kernbegrippe:}

Christelike perspektief en politieke kommunikasie negatiewe politieke boodskappe 
politieke kommunikasie

Suid-Afrikaanse verkiesings 